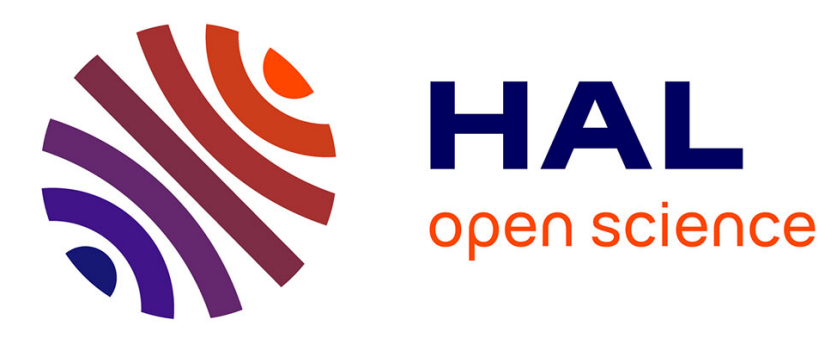

\title{
Physical investigations on (In2S3)x(In2O3)y and In2S3-xSex thin films processed through In2S3 annealing in air and selenide atmosphere
}

\author{
A Gantassi, Hatem Essaidi, K Boubaker, Christian Bernède, A Colantoni, \\ Mosbah Amlouk, Tahar Manoubi
}

\section{To cite this version:}

A Gantassi, Hatem Essaidi, K Boubaker, Christian Bernède, A Colantoni, et al.. Physical investigations on $(\mathrm{In} 2 \mathrm{~S} 3) \mathrm{x}(\mathrm{In} 2 \mathrm{O} 3) \mathrm{y}$ and In2S3-xSex thin films processed through In2S3 annealing in air and selenide atmosphere. Materials Science in Semiconductor Processing, 2014, 24, pp.237-246. 10.1016/j.mssp.2014.03.043 . hal-03350411

\section{HAL Id: hal-03350411 \\ https://univ-angers.hal.science/hal-03350411}

Submitted on 21 Sep 2021

HAL is a multi-disciplinary open access archive for the deposit and dissemination of scientific research documents, whether they are published or not. The documents may come from teaching and research institutions in France or abroad, or from public or private research centers.
L'archive ouverte pluridisciplinaire HAL, est destinée au dépôt et à la diffusion de documents scientifiques de niveau recherche, publiés ou non, émanant des établissements d'enseignement et de recherche français ou étrangers, des laboratoires publics ou privés. 


\title{
Physical investigations on $\left(\operatorname{In}_{2} \mathrm{~S}_{3}\right)_{x}\left(\operatorname{In}_{2} \mathrm{O}_{3}\right)_{y}$ and $\operatorname{In}_{2} \mathrm{~S}_{3-x} \mathrm{Se}_{x}$ thin films processed through $\operatorname{In}_{2} \mathrm{~S}_{3}$ annealing in air and selenide atmosphere
}

\author{
A. Gantassi ${ }^{a}$, H. Essaidi ${ }^{a}$, K. Boubaker ${ }^{\text {a,* }}$, J.C. Bernède ${ }^{b}$, A. Colantoni ${ }^{c}$, \\ M. Amlouk ${ }^{\mathrm{a}}$, T. Manoubi ${ }^{\mathrm{a}}$ \\ ${ }^{a}$ Unité de Physique des Dispositifs à Semi-conducteurs, Faculté des Sciences de Tunis, Campus Universitaire 2092 Tunis, Tunis El Manar \\ Université, Tunisia \\ ${ }^{\mathrm{b}} \mathrm{MOLTECH}-$ Anjou, Université d'Angers, Angers, France \\ ${ }^{\mathrm{c}}$ Department of Agriculture, Forest, Nature and Energy (DAFNE), University of Tuscia, Via S. Camillo de Lellis snc, 01100 Viterbo, Italy
}

\section{A R T I C L E I N F O}

Keywords:

$\mathrm{In}_{2} \mathrm{~S}_{3-x} \mathrm{Se}_{x}$

$\left(\operatorname{In}_{2} \mathrm{~S}_{3}\right)_{x}\left(\operatorname{In}_{2} \mathrm{O}_{3}\right)_{y}$

Thin films

Heat processing

Buffer layer

Urbach energy

\begin{abstract}
A B S T R A C T
$\mathrm{In}_{2} \mathrm{~S}_{3-x} \mathrm{Se}_{x}$ and $\left(\mathrm{In}_{2} \mathrm{~S}_{3}\right)_{x}\left(\mathrm{In}_{2} \mathrm{O}_{3}\right)_{y}$ thin films have been prepared on glass substrates using appropriate heat treatments of In evaporated thin films. X-ray analysis shows that In thin films which were annealed under sulfur atmosphere at $350{ }^{\circ} \mathrm{C}$ were mainly formed by $\operatorname{In}_{2} \mathrm{~S}_{3}$. A heat treatment of this binary in air at $400{ }^{\circ} \mathrm{C}$ during one hour leads to $\left(\operatorname{In}_{2} \mathrm{~S}_{3}\right)_{x}\left(\mathrm{In}_{2} \mathrm{O}_{3}\right)_{y}$ ternary material which has a tetragonal structure with a preferred orientation of the crystallites along the (109) direction. Similarly, a heat treatment of $\operatorname{In}_{2} \mathrm{~S}_{3}$ in selenium atmosphere at $350{ }^{\circ} \mathrm{C}$ during six hours leads to a new $\operatorname{In}_{2} \mathrm{~S}_{3-x} \mathrm{Se}_{x}$ ternary material having tetragonal body centered structure with a preferred orientation of the crystallites along the (109) direction. Optical band gap, refractive index and extinction coefficient values of $\operatorname{In}_{2} \mathrm{~S}_{3-x} \mathrm{Se}_{x}$ and $\left(\mathrm{In}_{2} \mathrm{~S}_{3}\right)_{x}\left(\mathrm{In}_{2} \mathrm{O}_{3}\right)_{y}$ thin films have been reached. Moreover, correlations between optical conductivity, XRD, AFM and Urbach energy of such ternary thin films have been discussed. Finally, the recorded formation disparity between the quaternary $\left(\operatorname{In}_{2} \mathrm{~S}_{3}\right)_{x}\left(\mathrm{In}_{2} \mathrm{O}_{3}\right)_{y}$ and ternary $\operatorname{In}_{2} \mathrm{~S}_{3-x} \mathrm{Se}_{x}$ compounds has been discussed in terms of the Simha-Somcynsky and Lattice Compatibility theories.
\end{abstract}

(c) 2014 Elsevier Ltd. All rights reserved.

\section{Introduction}

Interest in indium sulfide thin films has increased during the last ten years because of their high potential to be used as buffer layers in CuInS 2 based solar cells. $\operatorname{In}_{2} \mathrm{~S}_{3}$ exists in three different phases including the defective cubic $\alpha-\operatorname{In}_{2} \mathrm{~S}_{3}$ (stable up to $693 \mathrm{~K}$ ), the defect spinel structure, $\beta$ - $\operatorname{In}_{2} \mathrm{~S}_{3}$ (stable up to $1027 \mathrm{~K}$ ) and the layered structure $\gamma-\mathrm{In}_{2} \mathrm{~S}_{3}$ (above $1027 \mathrm{~K}$ ) [1,2]. A single crystal of

\footnotetext{
* Corresponding author. Tel.: +216 718726 00; fax: +216 71885073.

E-mail address: mmbb11112000@yhoo.fr (K. Boubaker).
}

indium sulfide is an n-type semiconductor with direct band gap energy in the range $2-2.3 \mathrm{eV}[3,4]$ following synthesis process; it is of great interest due to its potential application in picture tubes manufacturing [5], catalysis [6], and photovoltaic solar cells $[7,8]$. Its constitutive elements (indium and sulfur) are nontoxic and environmental friendly, which seems to be an ideal candidate to substitute highly toxic CdS as the buffer layer in CuInSe and CuInS 2 -based solar cells. Recently, it was reported that solar cells prepared using $\operatorname{In}_{2} \mathrm{~S}_{3}$ as buffer layer show $16.4 \%$ conversion efficiency, which is close to the typical solar cell using a CdS buffer layer [9]. Meanwhile, $\operatorname{In}_{2} \mathrm{~S}_{3}$ can also be used as precursors in the fabrication of compound 


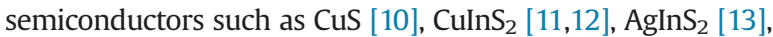
etc. A great deal of research effort has been devoted to developing effective approaches for $\operatorname{In}_{2} S_{3}$ synthesis. Various shapes of $\operatorname{In}_{2} \mathrm{~S}_{3}$ crystals such as nanoparticles [14], dendrites [15], one-dimensional nanostructures (including nanorods, wires, tubes) [16-18], chrysanthemum-like microspheres [19] and stacked superstructures [20] have been fabricated.

Indium sulfide films have been prepared by various techniques such as chemical bath deposition (CBD) [21], radio frequency (RF) magnetron sputtering [22], SILAR [23], organometallic chemical evaporation [24], chemical spray pyrolysis (CSP) [25-27], thermal evaporation [28], atomic layer epitaxy [29] and novel ultrasonic method [30].

However, several authors have found values higher than $2.3 \mathrm{eV}$. They explain this blue shift of the optical transmission threshold with the help of a different phenomenon. Kim et al. [31] have thus interpreted the broadening of their thin films band gap by the presence of an excess of sulfur in the bulk. Other authors have explained the broadening of the optical band gap of $\operatorname{In}_{2} \mathrm{~S}_{3}$ thin films by the quantum size effect $[32,33]$. So far, other possibilities can nevertheless be imagined, for example, indium can be partially substituted by aluminum in the $\operatorname{In}_{2} \mathrm{~S}_{3}$ matrix to form $\operatorname{In}_{2-2 x} \mathrm{Al}_{2 x} \mathrm{~S}_{3}$ [34] or sulfur can be partially substituted by oxygen to form $\operatorname{In}_{2} \mathrm{~S}_{3-3 x} \mathrm{O}_{3 x}[35,36]$.

In this paper $\left(\operatorname{In}_{2} \mathrm{~S}_{3}\right)_{x}\left(\mathrm{In}_{2} \mathrm{O}_{3}\right)_{y}$ and $\operatorname{In}_{2} \mathrm{~S}_{3-x} \mathrm{Se}_{x}$ thin films have been studied. A discussion between structural and optical properties of these films in terms of oxygen and selenium content is established.

\section{Experimental}

\subsection{Films preparation}

$\mathrm{In}_{2} \mathrm{~S}_{3-x} \mathrm{Se}_{x}$ and $\left(\mathrm{In}_{2} \mathrm{~S}_{3}\right)_{x}\left(\mathrm{In}_{2} \mathrm{O}_{3}\right)_{y}$ thin films preparation follows three steps. First, In thin films have been obtained by thermal evaporation, similar to the protocol detailed by [37]. Second, these films have undergone a heat treatment under sulfur atmosphere. Finally, on the one hand, an oxidation of the obtained $\mathrm{In}_{2} \mathrm{~S}_{3}$ films was carried out by means of a simple heat treatment in air. On the other hand, a thermal annealing in Se environment at $350{ }^{\circ} \mathrm{C}$ of the $\mathrm{In}_{2} \mathrm{~S}_{3}$ was carried out in a programmable tubular oven during six hours. The following sections reported some experimental details.

\subsubsection{Indium thin films}

Thin films of Indium element (99.999\% of purity) were obtained by evaporation in HV chamber using a relatively low pressure of the order of $2.5 \times 10^{-5}$ Torr. The films were deposited on $1 \times 2 \mathrm{~cm}^{2}$ glass substrates within substrate temperature $\mathrm{Ts}=100{ }^{\circ} \mathrm{C}$. This temperature is required to avoid the amorphous state of In thin film and to reinforce its adherence on the glass substrate. The typical deposition parameter of this metal corresponds to a growth rate of $3 \mathrm{~nm} \mathrm{~s}^{-1}$. Finally, the thickness of the indium is of the order of $150 \mathrm{~nm}$.

\subsection{2. $\mathrm{In}_{2} \mathrm{~S}_{3}$ thin films}

In thermal evaporated thin layers were placed into Pyrex pre-sealed in the presence of sulfur grains $(99.98 \%$ of purity). After that, the sample was heat-treated by annealing under vacuum $\left(10^{-3}\right.$ Torr $)$ at the rate of $3^{\circ} \mathrm{C} / \mathrm{min}$ from room temperature up to $350{ }^{\circ} \mathrm{C}$, for $6 \mathrm{~h}$ using a programmed tubular oven. Then, $\operatorname{In}_{2} \mathrm{~S}_{3}$ samples were cooled down.

\subsubsection{Oxidation}

In the first stage, the as-obtained $\operatorname{In}_{2} \mathrm{~S}_{3}$ thin films were annealed at $400{ }^{\circ} \mathrm{C}$ in air atmosphere during $1 \mathrm{~h}$ using a programmed tubular oven with a cooling rate of Pyrex tube of the order of $100{ }^{\circ} \mathrm{C} / \mathrm{h}$. A ternary compound based on In-S-O material was finally obtained.

\subsubsection{Selinization}

In the second stage, $\operatorname{In}_{2} S_{3}$ thin films were annealed at $350{ }^{\circ} \mathrm{C}$ in selenide environment under primary vacuum in the order of $10^{-3}$ Torr for six hours. A new ternary compound based on In-S-Se was found.

\subsection{Characterization techniques}

The spectra of X-ray diffraction of the prepared thin films were carried out at room temperature by a coppersource diffractometer (Analytical X Pert PROMP D), with a wavelength equal to $\lambda=1.54056 \AA$. 3D surface topography of the layers was performed by atomic force microscopy (VEECO digital instrument), operating in tapping mode to determine the roughness. Finally, the measurements of the optical transmission $T(\lambda)$ and reflection $R(\lambda)$ were performed using a Schimadzu UV 3100 double beam spectrophotometer equipped with an integrating sphere (LISR 3200 ) in the range of wavelength varying from 300 to $1800 \mathrm{~nm}$.

\section{Results and discussion}

\subsection{Structural study}

\subsection{1. $\mathrm{In}_{2} \mathrm{~S}_{3}$ oxidation}

Fig. 1a shows the X-ray diffraction analysis of as-deposited In thin film and also shows (101) and (202) principal orientations, which are characteristic of the indium material in tetragonal body centered phase (JCPDS: [05-0642]).

First, X-ray diffraction spectrum of $\mathrm{In}_{2} \mathrm{~S}_{3}$ thin film, which is obtained after a sulfuration process of In evaporated film for six hours at $350{ }^{\circ} \mathrm{C}$, is shown in Fig. $1 \mathrm{~b}$. The latest is mainly $\operatorname{In}_{2} S_{3}$ tetragonal body centered material (JCPDS: [25-0390]), with a preferred orientation of the crystallites along the (109) direction. Other peaks related to (112), (116), (206), (220) and (400) directions corresponding to the same structure are also found. It is also worth noting that no peak related to In element or indium oxide has been found in these spectra. This formation reaction of the material requires a thermodynamic activation to form indium sulfide at a critical annealing temperature equal to $350{ }^{\circ} \mathrm{C}$ according to the following endothermic reaction between sulfide and indium:

In $+3 \mathrm{~S} \rightarrow \mathrm{In}_{2} \mathrm{~S}_{3}$

Second, Fig. 1c shows the X-ray diffraction analysis of InSO thin films, which is obtained from an oxidation of 
a

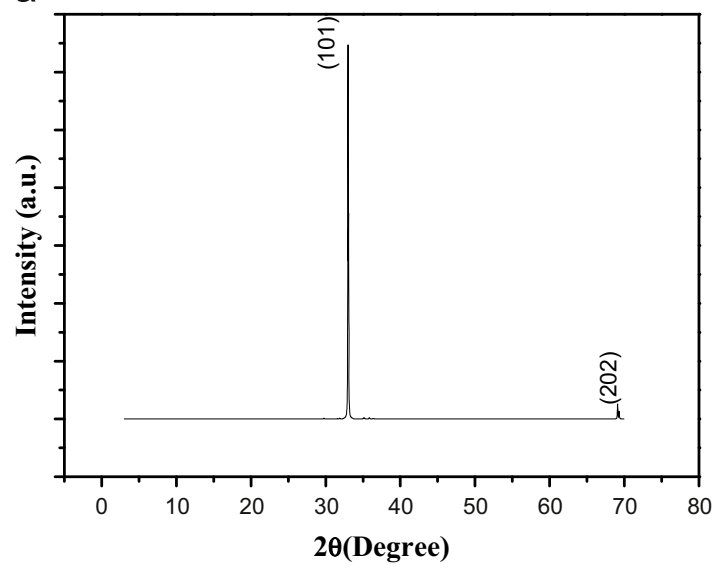

b

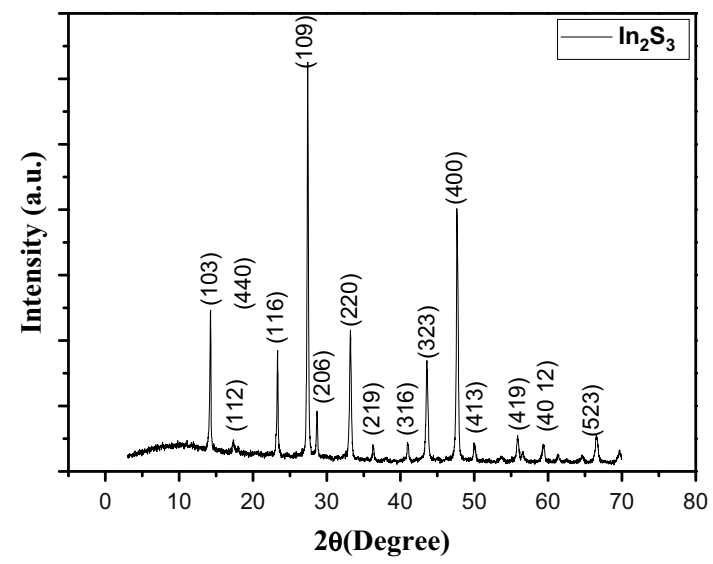

C

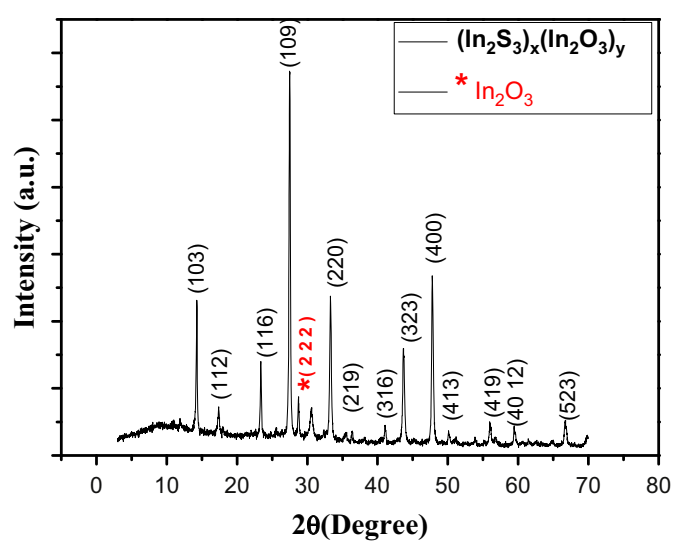

d

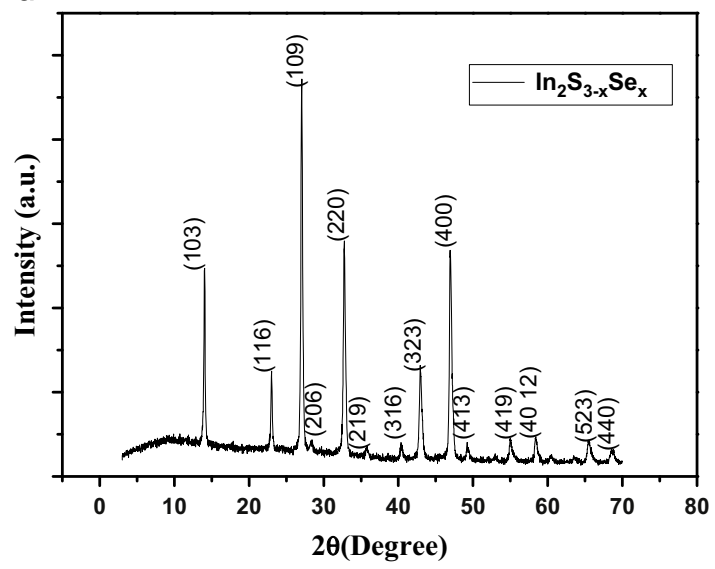

Fig. 1. (a) XRD spectra of In thin film. (b) XRD spectra of $\operatorname{In}_{2} \mathrm{~S}_{3}$ thin films. (c) XRD spectra of $\left(\operatorname{In}_{2} \mathrm{~S}_{3}\right)_{x}\left(\operatorname{In}_{2} \mathrm{O}_{3}\right)_{y}$ thin films. (d) XRD spectra of In $\mathrm{S}_{3}{ }_{-x} \mathrm{Se}_{x}$ thin films.

$\mathrm{In}_{2} \mathrm{~S}_{3}$ in air for one hour, showing that this ternary compound crystallizes in the tetragonal body centered phase (JCPDS: [25-0390] card), with a preferred orientation of the crystallites along the (109) direction. On the one hand, we note that the $\mathrm{In}_{2} \mathrm{O}_{3}$ secondary phase appeared with no negligible amount showing a preferential orientation along the (222) direction (JCPDS: [89-4595]). On the other hand, an accurate study of the evolution of the (109) position (Fig. 1) shows a clear shift toward large angles when $\mathrm{In}_{2} \mathrm{~S}_{3}$ is annealed in air. This shift regarding $d_{109}$ peak is probably due to the formation parallel to $\operatorname{In}_{2} S_{3}$ material, this results is in good agreement with literature $[35,36]$. Then, from Table 1 , we can see a small decrease of the lattice parameter from $a=7.626 \AA, c=32.350 \AA$ corresponding to $\operatorname{In}_{2} \mathrm{~S}_{3}$ to $(a=7.615 \AA, c=32.302 \AA)$ related to $\left(\mathrm{In}_{2} \mathrm{~S}_{3}\right)_{x}\left(\mathrm{In}_{2} \mathrm{O}_{3}\right)_{y}$. Thus, the film is really an alloy of $\left(\mathrm{In}_{2} \mathrm{~S}_{3}\right)_{x}\left(\mathrm{In}_{2} \mathrm{O}_{3}\right)_{y}$.

\subsection{2. $\mathrm{In}_{2} \mathrm{~S}_{3}$ selinization}

Fig. 1d shows the XRD spectra of $\operatorname{In}_{2} \mathrm{~S}_{3}$ thin films annealed under Selenium environment at $350{ }^{\circ} \mathrm{C}$ during six hours crystallization in the tetragonal body centered phase (JCPDS: [25-0390] card), with a preferred orientation of the crystallites along (109) direction.
Table 1

Texture coefficient of $\operatorname{In}_{2} \mathrm{~S}_{3},\left(\operatorname{In}_{2} \mathrm{~S}_{3}\right)_{x}\left(\operatorname{In}_{2} \mathrm{O}_{3}\right)_{y}$ and $\operatorname{In}_{2} \mathrm{~S}_{3-x} \mathrm{Se}_{x}$ thin films.

\begin{tabular}{lllllllll}
\hline \multirow{2}{*}{ Compounds } & \multicolumn{1}{l}{$T C_{(h k l)}$} \\
\cline { 2 - 8 } & $(103)$ & $(116)$ & $(109)$ & $(220)$ & $(323)$ & $(400)$ & $(523)$ \\
\hline ASTM: [25-0390] & 4.39 & 2.63 & 14.63 & 7.31 & 6.58 & 9.51 & 1.84 \\
$\left(I_{2} S_{3}\right)_{x}\left(I n_{2} \mathrm{O}_{3}\right)_{y}$ & 2.58 & 1.50 & 7.40 & 2.83 & 1.91 & 3.12 & 0.46 \\
$I_{2} S_{3}$ & 2.05 & 1.55 & 5.89 & 1.88 & 1.47 & 3.71 & 0.38 \\
$I_{2} S_{3-x} S_{x}$ & 2.50 & 0.98 & 4.55 & 2.92 & 1.31 & 2.96 & 0.29 \\
\hline
\end{tabular}

In Table 1, we summarize the reticular distance of (109) principal orientation and lattice constant as a function of the annealed temperature with $\mathrm{Se}$. We note that $d_{109}$ increases from $\operatorname{In}_{2} S_{3}$ value and reached the $\operatorname{In}_{2} \mathrm{Se}_{3}$ one. This shift regarding the $d_{109}$ peak is probably due to the incorporation of Se element in the $\mathrm{In}_{2} \mathrm{~S}_{3}$ matrix. This result has been found by other authors for the quaternary material $\mathrm{AgInS}_{2-x} \mathrm{Se}_{x}$ [41].

These results depict that the formation reaction of In$\mathrm{S}-\mathrm{Se}$ material goes on slowly and may require a thermodynamic activation. Thus, annealed films at $350{ }^{\circ} \mathrm{C}$ were marked by the appearance of novel diffraction peaks 
Table 2

Variation of crystallographic parameters, grain size and the strain of thin films $\operatorname{In}_{2} \mathrm{~S}_{3}, \operatorname{In}_{2} \mathrm{~S}_{3-x} \mathrm{Se}_{x}$ and $\left(\operatorname{In}_{2} \mathrm{~S}_{3}\right)_{x}\left(\mathrm{In}_{2} \mathrm{O}_{3}\right)_{y}$ annealed in air and Se atmosphere.

\begin{tabular}{|c|c|c|c|c|c|c|c|c|}
\hline \multirow[t]{2}{*}{ Compounds } & \multirow[t]{2}{*}{$2 \theta\left(^{\circ}\right)(109)$} & \multirow[t]{2}{*}{$d_{109}(\AA)$} & \multicolumn{2}{|c|}{ Parameter lattice } & \multirow[t]{2}{*}{$D(\mathrm{~nm})$} & \multirow[t]{2}{*}{$\varepsilon\left(10^{-3}\right)$} & \multirow[t]{2}{*}{$\delta\left(10^{14}\right.$ lines $\left./ \mathrm{m}^{2}\right)$} & \multirow[t]{2}{*}{$F W H M\left({ }^{\circ}\right)$} \\
\hline & & & $a(\AA)$ & $c(\AA)$ & & & & \\
\hline ASTM: [25-0390] & 27.4290 & 3.2490 & 7.619 & 32.329 & - & - & - & - \\
\hline$\left(\mathrm{In}_{2} \mathrm{~S}_{3}\right)_{x}\left(\mathrm{In}_{2} \mathrm{O}_{3}\right)_{y}$ & 27.4740 & 3.24653 & 7.615 & 32.302 & 47.5 & 2.986 & 4.43214 & 0.1673 \\
\hline $\mathrm{In}_{2} \mathrm{~S}_{3}$ & 27.4298 & 3.25166 & 7.626 & 32.350 & 54.3 & 2.693 & 3.39156 & 0.1506 \\
\hline $\mathrm{In}_{2} \mathrm{~S}_{3-x} S e_{x}$ & 26.9949 & 3.30305 & 9.342 & 25.762 & 59.2 & 2.738 & 2.85336 & 0.1506 \\
\hline
\end{tabular}

having other reticular distances $(d 1=630,638 \AA$, $d 2=$ $386,890 \AA$, $d 3=330,305 \AA$, $d 4=273,687 \AA$, d5 $=210,715 \AA$ and $d 6=193,652 \AA$ ), which do not belong to $\operatorname{In}_{2} S_{3}$ or $\mathrm{In}_{2} \mathrm{Se}_{3}$ materials. Moreover, the (112) direction remains very strong and the full-width at half-maximum (FWHM), which is very small (less than 0.2 ), shows a good crystal state of $\operatorname{In}_{2} \mathrm{~S}_{3-x} \mathrm{Se}_{x}$ films, Table 2. This phenomenon concerning the shift in the reticular distance can be explained by the formation of the ternary compound and the incorporation of Se that comes via this annealing process in the place of sulfur in the polycrystalline matrix. It is obviously noted that the lattice constant ( $a=9.342 \AA$ ) of the tetragonal structure values remains higher than the $\operatorname{In}_{2} S_{3}(a=7.619 \AA$ ) (JCPDS: [25-0390]) and the lattice constant $c=25.762 \AA$ is lower than $c=32.329 \AA$ [25-0390]. It seems that the two lattice constants go to a meeting point where $(a=c)$ and form a ternary compound based on $\operatorname{In}_{2} \mathrm{~S}_{3-x} \mathrm{Se}_{x}$ which has structure.

On the one hand, X-ray diffraction profiles can be used to calculate the grain size $D$, dislocation density $(\delta)$ and the microstrain $(\varepsilon)$ which play important roles in several properties such us thermal stability and mechanical properties of materials. The interplanar spacing $d_{h k l}$ values of $\mathrm{In}_{2} \mathrm{~S}_{3}, \mathrm{In}_{2} \mathrm{~S}_{3-x} \mathrm{Se}_{x}$ and $\left(\operatorname{In}_{2} \mathrm{~S}_{3}\right)_{x}\left(\operatorname{In}_{2} \mathrm{O}_{3}\right)_{y}$ thin films were calculated from the Bragg equation [38]

$2 d_{(h k l)} \sin \theta=n \lambda$

The grain size $D$ values are estimated from (102) diffraction lines of X-ray spectrum, using the DebyeScherer formula $[39,40]$

$D=\frac{0.9 \lambda}{\beta_{1 / 2} \cos \theta}$

where $D$ is the crystallite size, $\beta$ is the full width at half maximum (FWHM) of the diffraction peak located at $2 \theta$ and $\lambda$ is the X-ray wavelength (1.5406 $\AA$ ). The grain size is found to be around $89.35 \mathrm{~nm}$.

The dislocation density $(\delta)$ is given by [41]

$\delta=\frac{1}{D^{2}}$

The dislocation density $(\delta)$ varies between $2.85336 \times$ $10^{14}$ lines $/ \mathrm{m}^{2}$ and $4.43214 \times 10^{14}$ lines $/ \mathrm{m}^{2}$.

On the other hand, the microstrain $(\varepsilon)$ developed in $\mathrm{In}_{2} \mathrm{~S}_{3}$ thin films were calculated from the following relation [42]:

$\varepsilon=\frac{\beta_{1 / 2}}{4 \tan \theta}$
The microstrain $(\varepsilon)$ is of the order of $2.738 \times 10^{-3}$.

Moreover, the texture coefficient (TC) represents the texture of a particular plane, deviation of which from unity implies the preferred growth. Quantitative information concerning the preferential crystallite orientation was obtained from different texture coefficient $\mathrm{TC}_{(h k l)}$ defined by the well-known formula $[40,41]$

$\mathrm{TC}_{(h k l)}=\frac{I(h k l) / I_{0}(h k l)}{N^{-1} \sum} I(h k l) / I_{0}(h k l)$

where $I(h k l)$ is the measured relative intensity of a plane $(h k l), I_{0}(h k l)$ is the standard intensity of the plane $(h k l)$ taken from JCPDS data, $N$ is the reflection number and $n$ is the number of diffraction peaks. The calculated texture coefficients are listed in Table 1.

Tetragonal body centered lattice constants $a, b$ and $c$ of $\operatorname{In}_{2} \mathrm{~S}_{3}, \mathrm{In}_{2} \mathrm{~S}_{3-x} \mathrm{O}_{x}$ and $\left(\operatorname{In}_{2} \mathrm{~S}_{3}\right)_{x}\left(\operatorname{In}_{2} \mathrm{O}_{3}\right)_{y}$ thin films were calculated from the following lattice geometry equation:

$d_{(h k l)}=\frac{a}{\sqrt{h^{2}+k^{2}+\left(a^{2} / c^{2}\right) l^{2}}}$

The calculated values are given in Table 2. We note that these calculated values are in good agreement with JCPDS data. At first glance, it can be seen that the inter-planar spacing $d_{h k l}$ values decrease for $\left(\operatorname{In}_{2} \mathrm{~S}_{3}\right)_{x}\left(\mathrm{In}_{2} \mathrm{O}_{3}\right)_{y}$ when the binary $\mathrm{In}_{2} \mathrm{~S}_{3}$ annealed in air and increase when $\operatorname{In}_{2} \mathrm{~S}_{3}$ annealed under selenium atmosphere. This phenomenon can be related to the crystallite size, microstrain, structural disorder as well as the presence of impurities and defects in the material. In fact, X-ray diffraction (XRD) profile can be used to calculate the crystallite size $(D)$ and the microstrain $(\varepsilon)$, which played important roles in several properties such as thermal stability and mechanical properties of Stibnite phase. It is generally known that grain size and microstrain effects are inter-connected. The approach of Williamson and Hall is to assume a simple sum from both contributions. In terms of full-width of the diffraction line measured at halfmaximum intensity (FWHM), $\beta$ can be described as

$\beta \cos \theta=\frac{0.9 \lambda}{D}+4 \varepsilon \sin \theta$

where $\beta$ is the full width at half maximum (FWHM) of the diffraction peak located at $2 \theta$.

Eq. (5) represents a straight line between $2 \sin \theta$ ( $X$-axis) and $\beta \cos \theta$ ( $Y$-axis). The slope of the fitted straight line gives the strain $(\varepsilon)$ and intercept $(0.9 \lambda / D)$ of this line on the $Y$-axis gives crystallite size $(D)$, which is shown in Fig. 2. The calculated values of crystallite size and microstrain for different samples are presented in Table 3. 


\section{a}

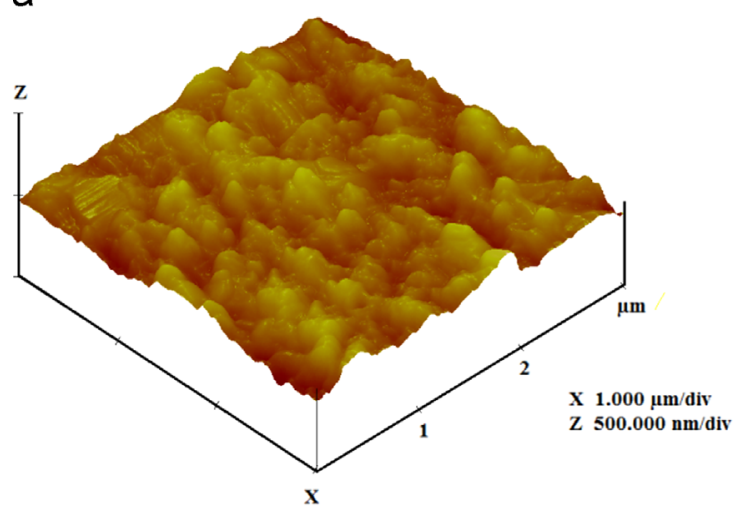

b

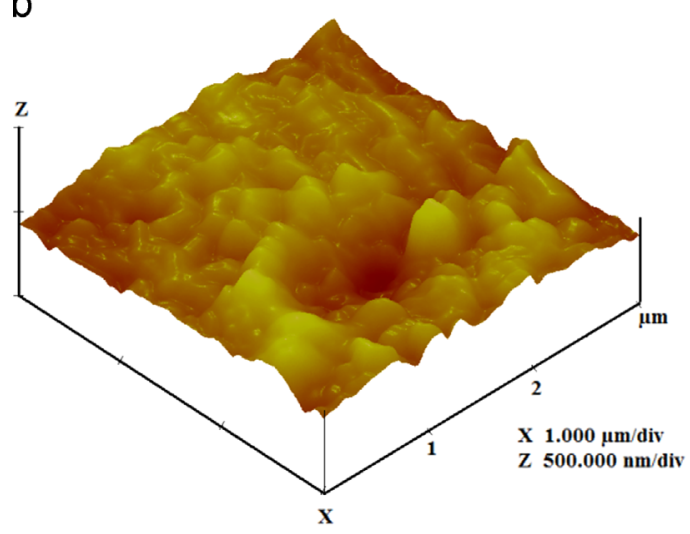

C

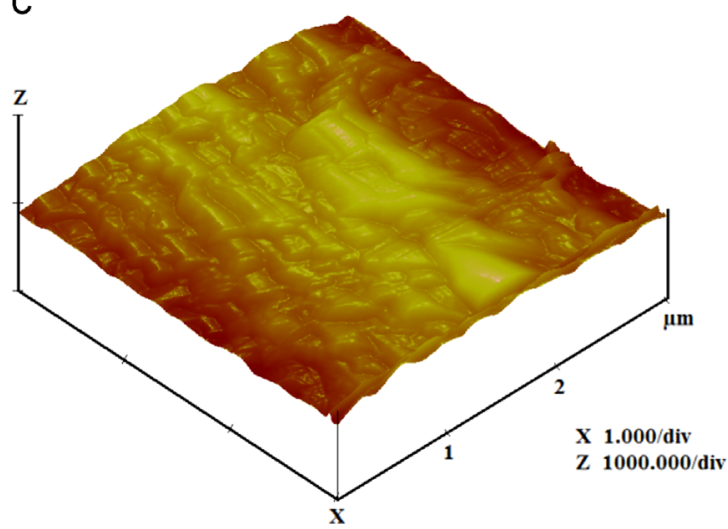

Fig. 2. (a) Surface topography $3 \mathrm{D}$ (AFM) of $\left(\operatorname{In}_{2} \mathrm{~S}_{3}\right)_{x}\left(\operatorname{In}_{2} \mathrm{O}_{3}\right)_{y}$ thin film. (b) Surface topography $3 \mathrm{D}$ (AFM) of $\operatorname{In}_{2} \mathrm{~S}_{3}$ thin films. (c) Surface topography 3D (AFM) of $\mathrm{In}_{2} \mathrm{~S}_{3-x} \mathrm{Se}_{x}$ thin films.

\subsection{Morphological characterization}

3D atomic force microscope (AFM) micrographs of thin films material $\operatorname{In}_{2} \mathrm{~S}_{3}, \operatorname{In}_{2} \mathrm{~S}_{3-x} \mathrm{Se}_{x}$ and $\operatorname{In}_{2} \mathrm{~S}_{3-x} \mathrm{O}_{x}$ obtained after annealing of $\operatorname{In}_{2} \mathrm{~S}_{3}$ in air and under selenide atmosphere are shown in Fig. 2. These micrographs reveal that all films surfaces are perturbed by clusters of rounded shapes and sizes and no cracks or holes have been found. The values of surface roughness of the layers obtained are
Table 3

Roughness of $\operatorname{In}_{2} \mathrm{~S}_{3}, \operatorname{In}_{2} \mathrm{~S}_{3-x} \mathrm{Se}_{x}$ and $\operatorname{In}_{2} \mathrm{~S}_{3-x} \mathrm{O}_{x}$ thin films.

\begin{tabular}{llll}
\hline Compounds & $\left(\mathrm{In}_{2} \mathrm{~S}_{3}\right)_{x}\left(\mathrm{In}_{2} \mathrm{O}_{3}\right)_{y}$ & $\mathrm{In}_{2} \mathrm{~S}_{3}$ & $\mathrm{In}_{2} \mathrm{~S}_{3-x} S e_{x}$ \\
\hline Roughness $(\mathrm{nm})$ & 31.208 & 50.922 & 75.052 \\
\hline
\end{tabular}

given in Table 2. We see that the roughness increases from $\left(\operatorname{In}_{2} \mathrm{~S}_{3}\right)_{x}\left(\operatorname{In}_{2} \mathrm{O}_{3}\right)_{y}$ to $\operatorname{In}_{2} \mathrm{~S}_{3-x} \mathrm{Se}_{x}$. This morphological study is consistent with the X-ray diffraction analysis described above.

\subsection{Optical study}

Fig. 3a and b shows the reflectance and transmission spectra of $\operatorname{In}_{2} \mathrm{~S}_{3}, \operatorname{In}_{2} \mathrm{~S}_{3-x} \mathrm{Se}_{x}$ and $\left(\operatorname{In}_{2} \mathrm{~S}_{3}\right)_{x}\left(\operatorname{In}_{2} \mathrm{O}_{3}\right)_{y}$ thin films recorded at room temperature within $300-2500 \mathrm{~nm}$ wavelength range. The optical transmission $T(\lambda)$ indicates indeed that this film is transparent (transmittance around $70 \%$ ) in the visible and near infrared regions and the reflection $R(\lambda)$ spectra are relatively low. We note that $T(\lambda)$ and $R(\lambda)$ spectra recorded in the visible as well as in near IR regions (300-2500 nm) do not exhibit interference fringes, which proves that the power distribution of such layers is large enough. Fig. 4.

The refractive index $n(\lambda)$ and the extinction coefficient $k$ ( $\lambda$ ) were calculated using the Mueller numerical method of resolution of nonlinear equation reported elsewhere $[43,44]$. The plots of $n(\lambda)$ and $k(\lambda)$ are shown in Fig. 5a and $\mathrm{b}$. It is observed that the refractive index value varies in 2-3.5 domain, whereas the extinction coefficient ranges from 0.0001 to 0.0025 for visible and near infrared regions.

Nevertheless, the dispersion of the refractive index is fitted by the Cauchy formula as follows [45]:

$n=A+\frac{B}{\lambda^{2}}$

where $A$ and $B$ are constants.

$A$ and $B$ values of $\operatorname{In}_{2} \mathrm{~S}_{3}, \operatorname{In}_{2} \mathrm{~S}_{3-x} \mathrm{Se}_{x}$ and $\left(\operatorname{In}_{2} \mathrm{~S}_{3}\right)_{x}\left(\operatorname{In}_{2} \mathrm{O}_{3}\right)_{y}$ thin film are listed in Table 2. On the other hand, the refractive index reaches a peak located at $k=469 \mathrm{~nm}$, but at higher wavelength, the refractive index tends to be constant and the film becomes non-dispersive. It is found that the refractive index shows an anomalous dispersion at the lower wavelengths and rather a normal dispersion at the higher wavelengths region. Also, the refractive index at photon energies below the inter-band absorption edge was evaluated according to the semi-empirical model proposed by Wemple and DiDomenico [46,47]:

$n^{2}-1=\frac{E_{0} E_{d}}{E_{0}^{2}-(h v)^{2}}$

where $E_{0}$ and $E_{d}$ are single-oscillator constants. $E_{0}$ is the average excitation energy for electronic transitions and $E_{d}$ is the dispersion energy which is a measure of the strength of interband optical transitions and it is associated with the changes in the structural order of the material and the effective oscillator energy. 
a

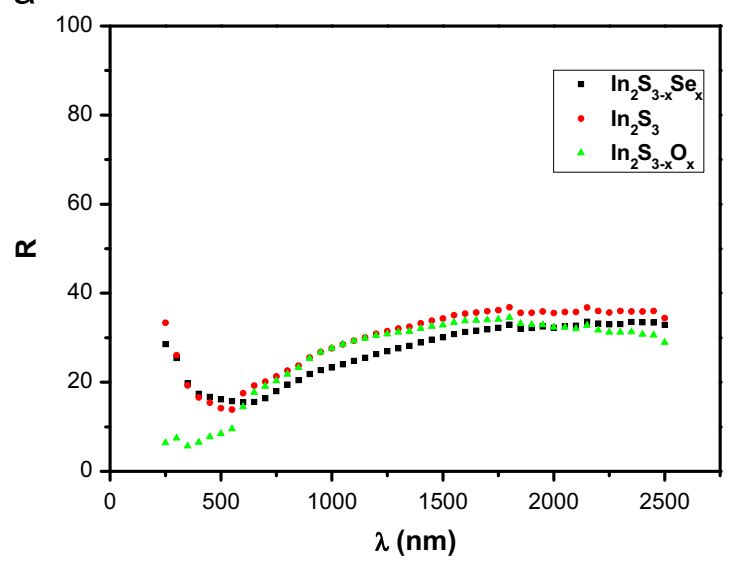

b

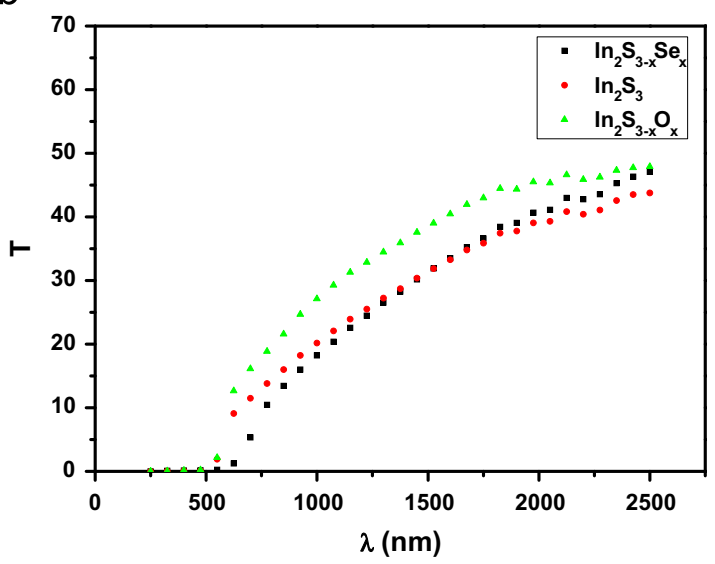

Fig. 3. (a) Reflectance spectra of $\operatorname{In}_{2} \mathrm{~S}_{3}, \mathrm{In}_{2} \mathrm{~S}_{3-x} \mathrm{Se}_{x}$ and $\left(\operatorname{In}_{2} \mathrm{~S}_{3}\right)_{x}\left(\mathrm{In}_{2} \mathrm{O}_{3}\right)_{y}$ thin films. (b) Transmission spectra of $\operatorname{In}_{2} \mathrm{~S}_{3}, \mathrm{In}_{2} \mathrm{~S}_{3-x} \mathrm{Se}_{x}$ and $\left(\operatorname{In}_{2} \mathrm{~S}_{3}\right)_{x}$ $\left(\mathrm{In}_{2} \mathrm{O}_{3}\right)_{y}$ thin films.

The linear variation of $\left(n^{2}-1\right)^{-1}$ versus $(h v)^{2}$ for $\operatorname{In}_{2} \mathrm{~S}_{3}$, $\operatorname{In}_{2} \mathrm{~S}_{3-x} \mathrm{Se}_{x}$ and $\left(\operatorname{In}_{2} \mathrm{~S}_{3}\right)_{x}\left(\operatorname{In}_{2} \mathrm{O}_{3}\right)_{y}$ thin films is shown in Fig. $6 \mathrm{a}, \mathrm{b}$ and $\mathrm{c}$. This plot achieves both $E_{0}$ and $E_{d}$ constants. Their values are gathered in Table 2. It is noted that the oscillator energy $E_{0}$ value is close to $2.5 E_{g}$, as suggested by the WDD model.

The absorption coefficient $\alpha$ can be obtained from the experimentally measured values of $R(\lambda)$ and $T(\lambda)$ in the strong absorption region according to the following expression:

$\alpha=\frac{1}{e} \ln \left[\frac{(1-R)^{2}+\left[(1-R)^{4}+4 R^{2} T^{2}\right]^{1 / 2}}{2 T}\right]$

where $e$ is the sample thickness.

The logarithm of the absorption coefficient $\alpha(\nu)$ is plotted as a function of the photon energy $(h \nu)$ for different compounds and is shown in Fig. 6. It can be seen that all the films have relatively high absorption coefficients $\left(10^{4}-10^{6} \mathrm{~cm}^{-1}\right)$.

In many materials, it is assumed that the absorption coefficient $\alpha$ near the band edge shows an exponential dependence on photon energy $h v$. This dependence is

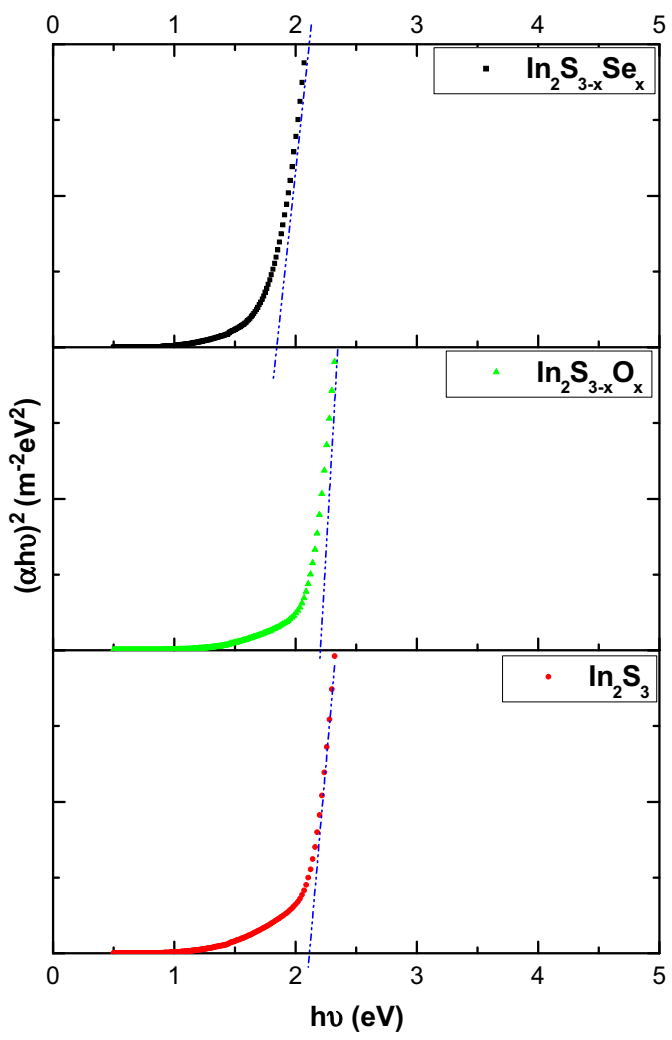

Fig. 4. Plot of $(\alpha h v)^{2}$ versus $(h v)$ of $\operatorname{In}_{2} \mathrm{~S}_{3}, \operatorname{In}_{2} \mathrm{~S}_{3-x} \mathrm{Se}_{x}$ and $\left(\operatorname{In}_{2} \mathrm{~S}_{3}\right)_{x}\left(\operatorname{In}_{2} \mathrm{O}_{3}\right)_{y}$ thin films.

given by the relation obtained from Urbach energy tailing which characterizes the optical absorption in this material. The Urbach energy tailing of the optical absorption edge in the material follows the empirical Urbach law $[48,49]$

$\alpha(h \nu)=\alpha_{0} e^{h_{\nu} / E_{u}}$

$E_{u}=\left[\frac{d \ln \alpha}{d h \nu}\right]^{-1}$

where $\alpha_{0}$ is a constant and $E_{u}$ is the Urbach energy.

The Urbach energy characterizes local defects which create localized states in the band gap. In fact, the disorder is associated with structural defects in the material, which leads to an extension of the density of states in the band tails. This results in a non-zero absorption for photon energies below the band gap energy. The experimental value of Urbach energy $E_{u}$ was derived from the slope of the straight line portion of the plots of $\ln (\alpha)$ versus $h \nu$ (Fig. 6), using the following equation:

$\ln (\alpha)=\ln \left(\alpha_{0}\right)+h \nu / E_{u}$

The values of Urbach energy $E_{u}$ for different thin films are gathered in Table 3. Urbach's energy increases from $\left(\operatorname{In}_{2} \mathrm{~S}_{3}\right)_{x}\left(\operatorname{In}_{2} \mathrm{O}_{3}\right)_{y}$ to $\mathrm{In}_{2} \mathrm{~S}_{3-x} \mathrm{Se}_{x}$. In addition, the 3D AFM micrographs of thin films (c) show that crystallite-like rods puffed and randomly oriented. This behavior can be related to the degree of structural disorder for this material. Also, to study the effect of crystallite size on the optical band gap of the films, we calculated the band gap 
a

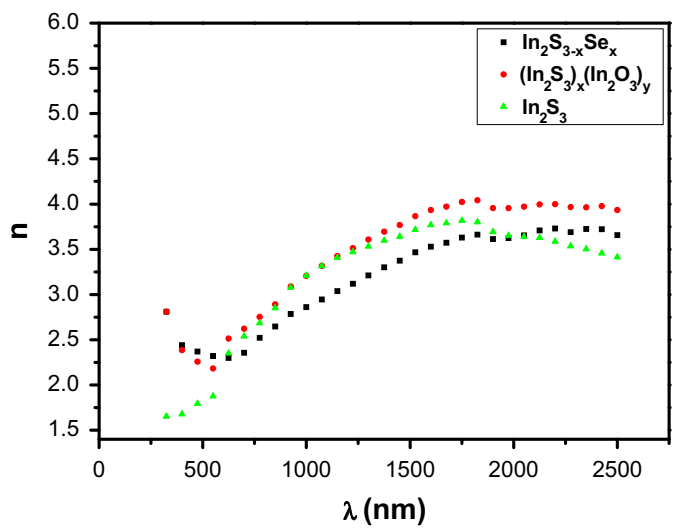

b

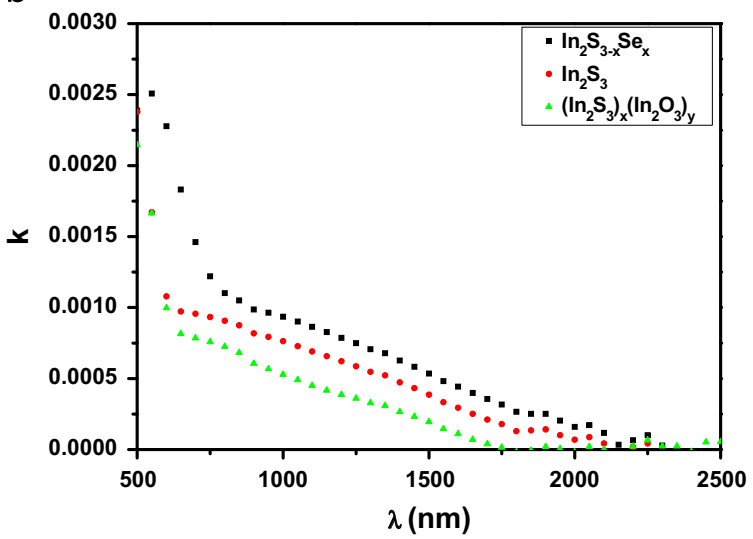

Fig. 5. (a) Dispersion of refractive index for wavelength $\lambda$ of $\operatorname{In}_{2} \mathrm{~S}_{3}$, $\mathrm{In}_{2} \mathrm{~S}_{3-x} \mathrm{Se}_{x}$ and $\left(\mathrm{In}_{2} \mathrm{~S}_{3}\right)_{x}\left(\mathrm{In}_{2} \mathrm{O}_{3}\right)_{y}$ thin films. (b) Dispersion of extinction coefficient for wavelength $\lambda$ of $\operatorname{In}_{2} \mathrm{~S}_{3}, \mathrm{In}_{2} \mathrm{~S}_{3-x} \mathrm{Se}_{x}$ and $\left(\mathrm{In}_{2} \mathrm{~S}_{3}\right)_{x}\left(\mathrm{In}_{2} \mathrm{O}_{3}\right)_{y}$ thin films.

energy. The optical band gap is estimated using the following relation [50]:

$(\alpha h \nu)^{2}=A\left(E_{g}-h \nu\right)$

where $A$ is a constant, $h_{\nu}$ is the photon energy and $E_{g}$ is the optical band gap. The plot of $(\alpha h \nu)^{2}$ versus the incident photon energy $(h \nu)$ shows a linear variation indicating direct transitions (Fig. 7). The extrapolation of the intersection of the line with the $y$-axis gives the value of the optical band gap of this compound. The values of optical band gap energy for different films are listed in Table 3. We noticed that these values decrease from $2.2 \mathrm{eV}$ for $\left(\operatorname{In}_{2} \mathrm{~S}_{3}\right)_{x}\left(\operatorname{In}_{2} \mathrm{O}_{3}\right)_{y}$ to $1.84 \mathrm{eV}$ for $\operatorname{In}_{2} \mathrm{~S}_{3-x} \mathrm{Se}_{x}$; those results are again in good agreement with the X-ray diffraction analysis. On the other hand, the optical band gap energy value of our materials thin films decreases from 2.2 to $1.84 \mathrm{eV}$ as the crystallite size value increases from 47 to $59 \mathrm{~nm}$, reflecting a noticeable change in the structural, optical and morphological properties. The decrease in $E_{g}$ value of the crystalline thin films can be attributed to the incorporation of $\mathrm{O}$ and Se elements in $\operatorname{In}_{2} \mathrm{~S}_{3}$ thin films.

We note that the optical band gap $(1.84-2.20 \mathrm{eV})$ covers the maximum of the visible and near infrared ranges of the solar spectrum. Table 4 .
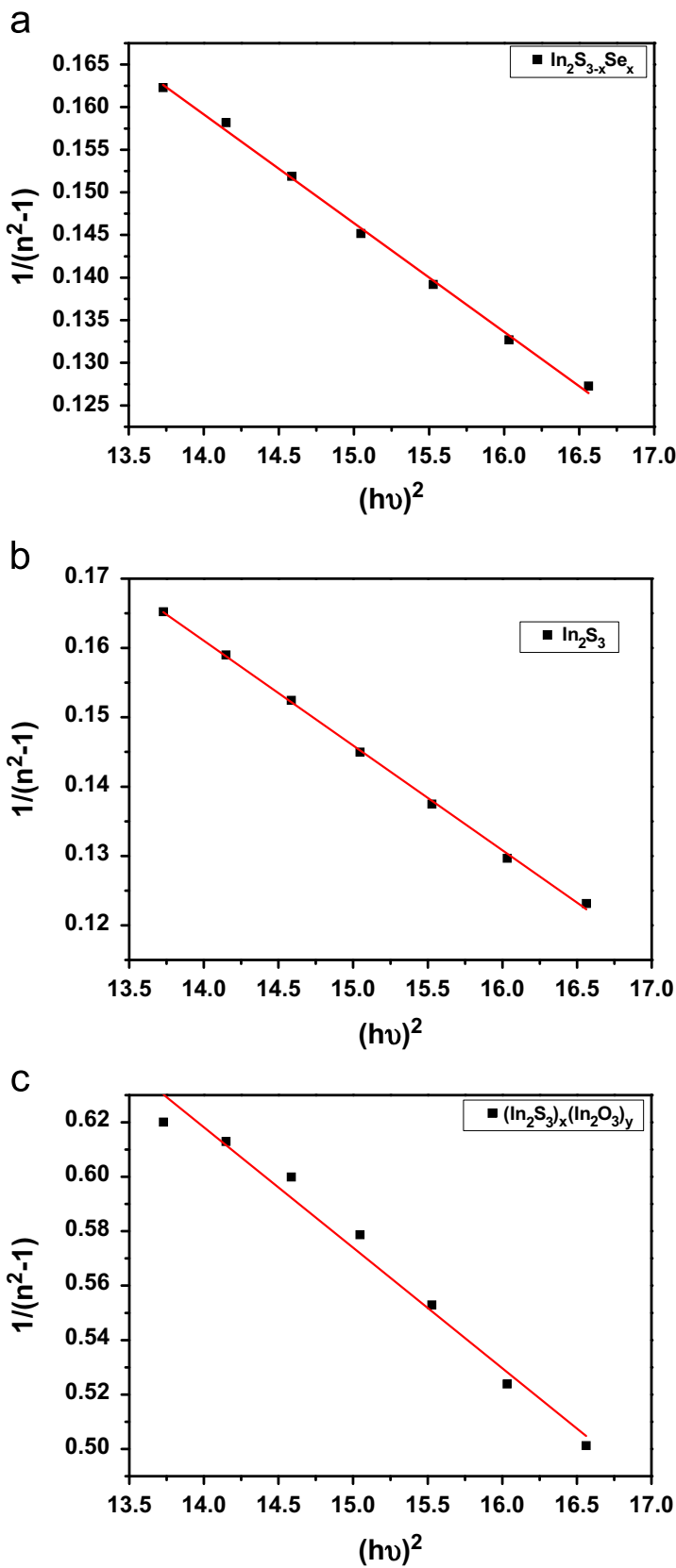

Fig. 6. (a) Plot of $\left(n^{2}-1\right)^{-1}$ versus $(h v)^{2}$ for the $\operatorname{In}_{2} \mathrm{~S}_{3-x} \mathrm{Se}_{x}$ thin film. (b) Plot of $\left(\mathrm{n}^{2}-1\right)^{-1}$ versus $(h v)^{2}$ for the $\operatorname{In}_{2} \mathrm{~S}_{3}$ thin film. (c) Plot of $\left(n^{2}-1\right)^{-1}$ versus $(h v)^{2}$ for the $\left(\operatorname{In}_{2} \mathrm{~S}_{3}\right)_{x}\left(\operatorname{In}_{2} \mathrm{O}_{3}\right)_{y}$ thin film.

In fact, the dielectric constants are defined by the following equations:

$$
\begin{aligned}
& \varepsilon(\lambda)=(n(\lambda)-i k(\lambda))^{2}=\varepsilon_{1}(\lambda)-i \varepsilon_{2}(\lambda) \\
& \varepsilon_{1}(\lambda)=n(\lambda)^{2}-k(\lambda)^{2} \\
& \varepsilon_{2}(\lambda)=2 n(\lambda) k(\lambda)
\end{aligned}
$$

Using the experimental data values of the refractive index and the extinction coefficient, the values of dielectric constants are deducted. 
a

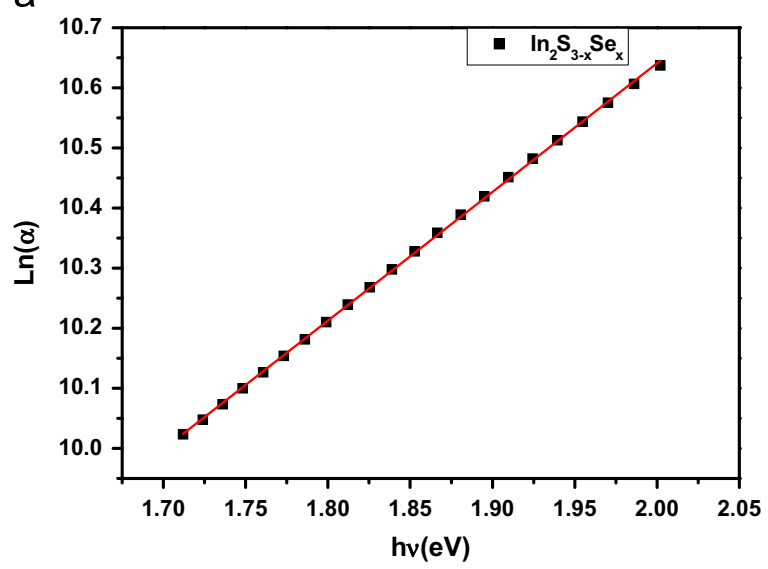

b

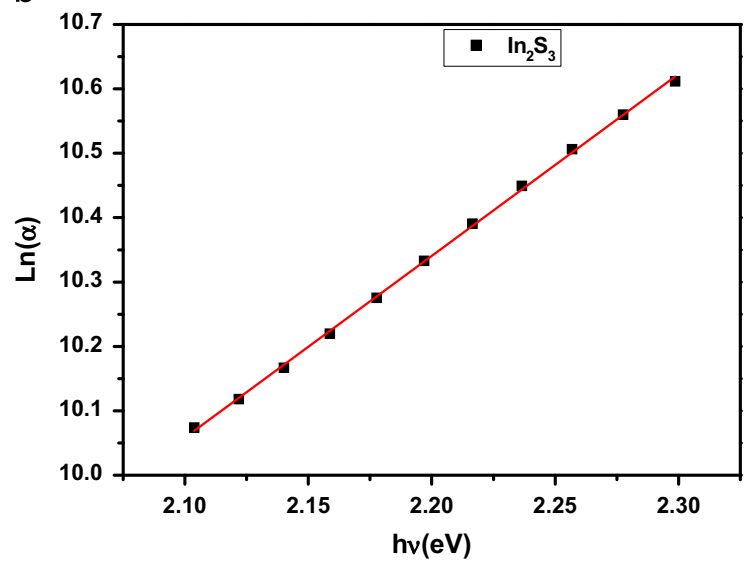

C

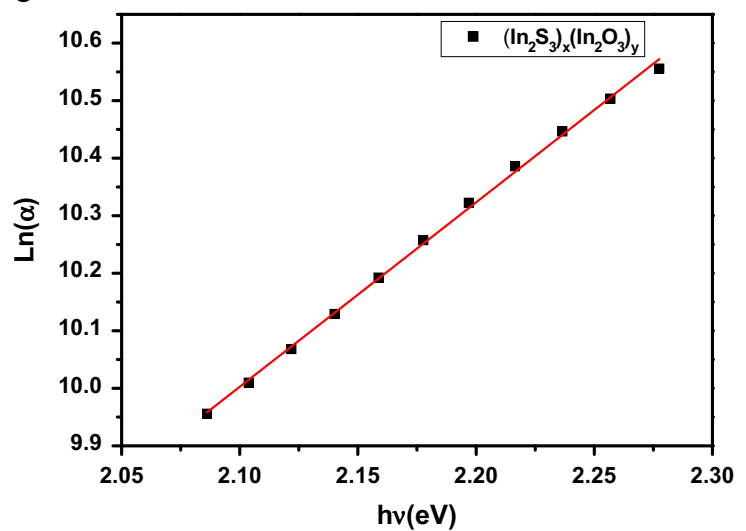

Fig. 7. (a) Variation of $\ln (\alpha)$ versus ( $h v)$ of $\operatorname{In}_{2} \mathrm{~S}_{3-x} \mathrm{Se}_{x}$ thin film. (b) Variation of $\ln (\alpha)$ versus ( $h v)$ of $\operatorname{In}_{2} \mathrm{~S}_{3}$ thin film. (c) Variation of $\ln (\alpha)$ versus $(h v)$ of $\left(\operatorname{In}_{2} \mathrm{~S}_{3}\right)_{x}\left(\operatorname{In}_{2} \mathrm{O}_{3}\right)_{y}$ thin film.
In the infrared domain dielectric constants $\varepsilon_{1}(\lambda)$ and $\boldsymbol{\varepsilon}_{2}(\lambda)$ may be expressed in terms of wavelength $\lambda$ as follows:

$\varepsilon_{1}(\lambda)=\varepsilon_{\infty}-\frac{\varepsilon_{\infty} \omega_{p}^{2}}{4 \pi^{2} c^{2}} \lambda^{2}$

$\varepsilon_{2}(\lambda)=\frac{\varepsilon_{\infty} \omega_{p}^{2}}{8 \pi^{3} c^{3} \tau} \lambda^{3}$

$\omega_{p}^{2}=\frac{4 \pi N e^{2}}{\varepsilon_{\infty} m_{e}^{*}}$.

where $\tau$ is the relaxation time, $e 1$ is the high frequency limit-value of the dielectric constant, $\omega_{p}$ is the plasma frequency, $N$ is the charge carriers density and $m$ is the effective mass of the charge carrier.

\subsection{Simha-Somcynsky and Lattice Compatibility theories analyses}

In the case of the actually synthesized compounds, the impossibility of obtaining the ternary $\operatorname{In}_{2} \mathrm{~S}_{3-x} \mathrm{O}_{x}$-like compounds, contrary to $\mathrm{In}_{2} \mathrm{~S}_{3-x} \mathrm{Se}_{x}$, was an intriguing problem. This difficulty has already been evoked by Newell et al. [51] who suspected the formation of this compound during electrodeposition of indium sulfide films, as golden-yellow films, depositing typically heavier around the substrate edges. A recent patent of Bernède et al. [52] claimed also the aggregation of a particular beta- $\operatorname{In}_{2} \mathrm{~S}_{3-x} \mathrm{O}_{x}$ compound where $x=0.15-0.35$, during vacuum vapor deposition of indium and sulfur layers from solid sources and heat treatment in an oxygen-containing inert gas stream for 25-35 min at 615-635 K. Nevertheless, in both cases no supported evidence has been supplied. According to the generalized Simha-Somcynsky theory [53,54], any ternary or quaternary lattice can be considered as a succession of elementary molecules and holes. Each cell in the occupied fraction is either empty or contains the molecule van-der-Waals volume as well as an inherent free volume. The total occupied volume fraction within the lattice is hence coupled with temperature and atoms size. Fig. 8.

The Lattice Compatibility Theory, as mentioned in some recent studies [29-31], and as associated with the SimhaSomcynsky principles [53], explains some aspects of the interaction between lattice elements. Patterns of this theory have been established by Boubaker et al. [55-58] in the context of analyzing Urbach's tailing controversial behavior in some nanocompounds as well as I-III- $\mathrm{O}_{2}$ ternary oxides instability at low temperatures. It was also confirmed by Petkova et al. [58] on the bases of investigation on some copper-doped compounds. An original

Table 4

Optical properties of $\operatorname{In}_{2} \mathrm{~S}_{3}, \operatorname{In}_{2} \mathrm{~S}_{3-x} \mathrm{Se}_{x}$ and $\left(\operatorname{In}_{2} \mathrm{~S}_{3}\right)_{x}\left(\operatorname{In}_{2} \mathrm{O}_{3}\right)_{y}$ thin films.

\begin{tabular}{|c|c|c|c|c|c|c|}
\hline Compounds & $E_{g}(e V)$ & $E_{U}(\mathrm{meV})$ & $A$ & $B$ & $E_{0}(e V)$ & $E_{d}(e V)$ \\
\hline$\left(\mathrm{In}_{2} \mathrm{~S}_{3}\right)_{x}\left(\mathrm{In}_{2} \mathrm{O}_{3}\right)_{y}$ & 2.20 & 311.83 & 1.23791 & 0.04426 & 5.28833 & 4.27200 \\
\hline $\mathrm{In}_{2} \mathrm{~S}_{3}$ & 2.12 & 354.22 & 0.37272 & 0.01512 & 4.96511 & 13.32129 \\
\hline $\mathrm{In}_{2} \mathrm{~S}_{3-x} \mathrm{Se}_{x}$ & 1.84 & 467.04 & 0.33773 & 0.01276 & 5.14469 & 15.23316 \\
\hline
\end{tabular}


formulation of the Lattice Compatibility Theory [55-58] has been established as follows:

"The stability of doping agents inside host structures is favorized by geometrical compatibility, expressed in terms of matching patterns between doping agent intrinsic lattice and those of the host".

a

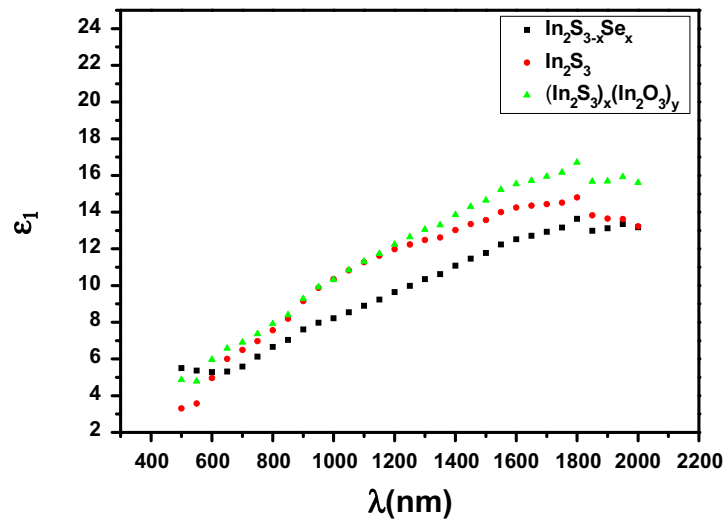

b

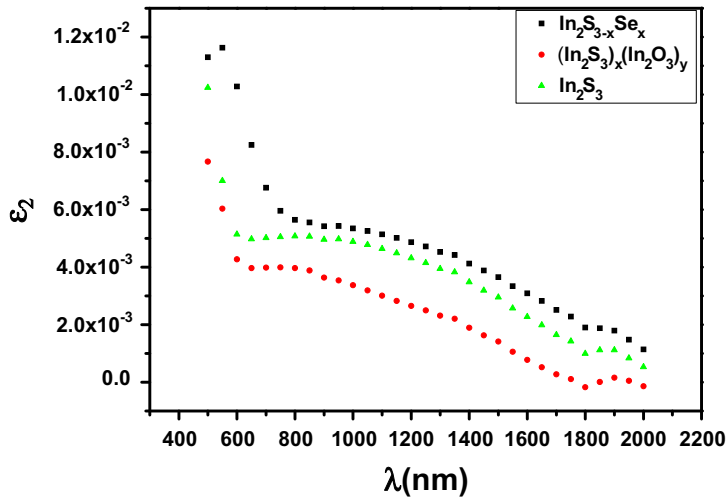

Fig. 8. (a) Variation of $\varepsilon_{1}$ versus $\lambda$ of $\operatorname{In}_{2} \mathrm{~S}_{3}, \operatorname{In}_{2} \mathrm{~S}_{3-x} \mathrm{Se}_{x}$ and $\left(\mathrm{In}_{2} \mathrm{~S}_{3}\right)_{x}\left(\operatorname{In}_{2} \mathrm{O}_{3}\right)_{y}$ thin films. (b) Variation of $\varepsilon_{2}$ versus $\lambda$ of $\operatorname{In}_{2} \mathrm{~S}_{3}, \operatorname{In}_{2} \mathrm{~S}_{3-x} \mathrm{Se}_{x}$ and $\left(\mathrm{In}_{2} \mathrm{~S}_{3}\right)_{x}$ $\left(\mathrm{In}_{2} \mathrm{O}_{3}\right)_{y}$ thin films
In the actually discussed case $\left(\operatorname{In}_{2} \mathrm{~S}_{3-x} \mathrm{Se}_{x}\right.$ and $\left(\operatorname{In}_{2} \mathrm{~S}_{3}\right)_{x}$ $\left(\mathrm{In}_{2} \mathrm{O}_{3}\right)_{y}$ lattices), answers to the evoked intrigue can be discussed by the nature of the highest occupied bands, and the location of holes in $\operatorname{In}_{2} \mathrm{~S}_{3}$ lattice structures as hosts to the two candidates: Se and O. In this context, fundamental geometrical observations concerning the structure of the binary $\mathrm{SeO}_{3}$ (Fig. 9) and host $\mathrm{In}_{2} \mathrm{~S}_{3}$ matrix were interpreted in terms of conventional lattice-linked parameters $\left(z_{0}, x^{\prime}, x^{\prime \prime}, y_{\text {.. }}\right)$ in Fig. 9. The similarities between the two structures, as evoked elsewhere by Cheng et al. [60], He et al. [61], and Charpentier et al. [62] in favor of an easier substitution process between sulfur and selenium ions within ternary structures, are contrary to those of oxygen and sulfur.

The Lattice Compatibility Theory LCT hence gives an explanation to the prior incorporation of Se in the $\operatorname{In}_{2} \mathrm{~S}_{3}$ tetragonal matrix by taking sulfur's place, as confirmed earlier by the recorded XRD peak shift (Section 3.1.2).

\section{Conclusion}

$\mathrm{In}_{2} \mathrm{~S}_{3-x} \mathrm{Se}_{x}$ and $\left(\mathrm{In}_{2} \mathrm{~S}_{3}\right)_{x}\left(\mathrm{In}_{2} \mathrm{O}_{3}\right)_{y}$ thin films have been prepared using a low-cost protocol using a heat treatment of $\mathrm{In}_{2} \mathrm{~S}_{3}$ films in selenium atmosphere and in air. XRD analysis confirms that the films annealed at $\operatorname{Tr}=350{ }^{\circ} \mathrm{C}$ under selenium atmosphere is mainly formed of $\operatorname{In}_{2} \mathrm{~S}_{3-x}$ $\mathrm{Se}_{x}$ tetragonal body centered phase and the film annealed in air at $\operatorname{Tr}=400{ }^{\circ} \mathrm{C}$ proves that the oxygen element incorporated in the $\operatorname{In}_{2} \mathrm{~S}_{3}$ matrix. XRD and AFM measurements indicated that the grain size and parameter lattice are changed from $\left(\operatorname{In}_{2} \mathrm{~S}_{3}\right)_{x}\left(\operatorname{In}_{2} \mathrm{O}_{3}\right)_{y}$ to $\operatorname{In}_{2} \mathrm{~S}_{3-x} \mathrm{Se}_{x}$. Further decrease in the optical band gap observed for our compounds films is attributed to the increase in the grain size. Second, the optical band gap energy, the Urbach energy as well as extinction coefficient and refractive index are calculated from optical spectra. Summarizing, we have shown that the crystallite size in our materials thin films strongly influences their physical properties. These observations could be useful while considering these films for optoelectronic applications like buffer layer in solar cells.
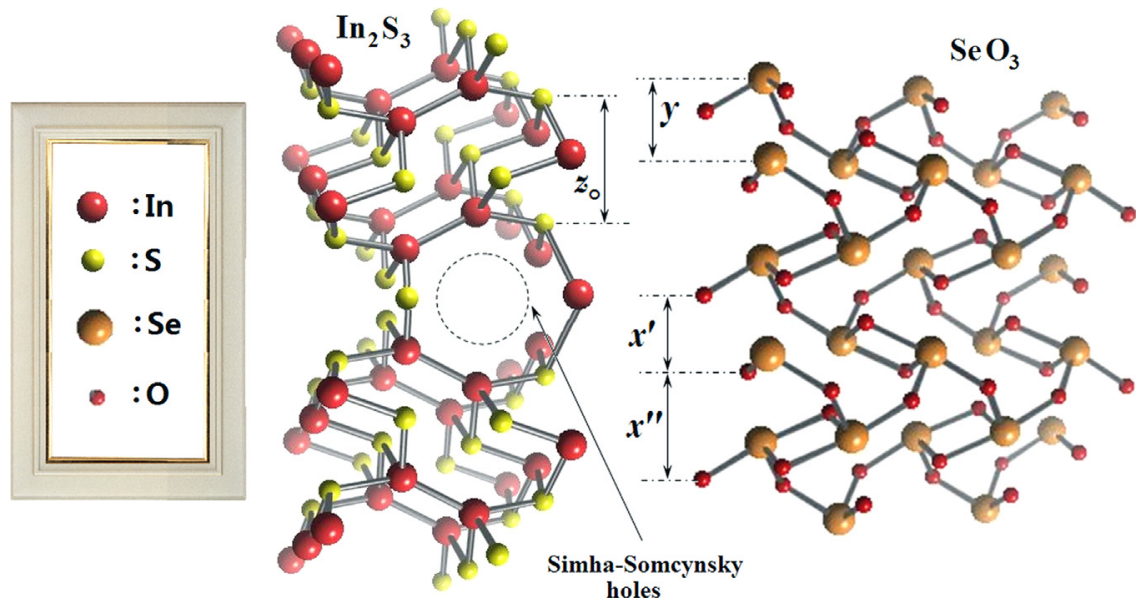

Fig. 9. Simha-Somcynsky configuration along with Lattice Compatibility Theory LCT patterns $\left(\operatorname{In}_{2} \mathrm{~S}_{3}\right.$ and $\mathrm{SeO}_{3}$ lattices). 


\section{References}

[1] L. Zhang, W. Zhang, Haibin Yang, Wuyou Fu, Minghui Li, Hui Zhao Jinwen Ma, Appl. Surf. Sci. 258 (2012) 9018-9024.

[2] Z. Hua Gao, Jingbing Liu, Hao Wang, Mater. Sci. Semicond. Process. 15 (2012) 187-193.

[3] P.M. Sirimanne, S. Shiozaki, N. Sonoyama, T. Sakata, Sol. Energy Mater. Sol. Cells 62 (2000) 247.

[4] J. Herrero, J. Ortega, Sol. Energy Mater. 17 (1988) 357.

[5] S. Yu, L. Shu, Y. Qian, Y. Xie, J. Yang, L. Yang, Mater. Res. Bull. 33 (1998) 717-721.

[6] Y. He, D. Li, G. Xiao, W. Chen, Y. Chen, M. Sun, H. Huang, X. Fu, J. Phys. Chem. C 113 (2009) 5254-5262.

[7] A. Belaidi, T. Dittrich, D. Kieven, J. Tornow, K. Schwarzburg, M. Kunst, N. Allsop, M.C. Lux-Steiner, S. Gavrilov, Sol. Energy Mater. Sol. Cells 93 (2009) 1033-1036.

[8] T. Dittrich, D. Kieven, A. Belaidi, M. Rusu, J. Tornow, K. Schwarzburg, M.C. Lux-Steiner, J. Appl. Phys. 105 (2009) 034509.

[9] N. Naghavi, S. Spiering, M. Powalla, B. Cavana, D. Lincot, Prog. Photovolt.: Res. Appl. 11 (2003) 437-443.

[10] X. Sheng, L. Wang, G. Chen, D. Yang, J. Nanomater. 2011 (2011) 280216.

[11] Y. Peña, S. Lugo, M. Calixto-Rodriguez, A. Vazquez, I. Gomez, P. Elizondo, Appl. Surf. Sci. 257 (2011) 2193-2196.

[12] M. Ge, C. Guo, L. Liu, B. Zhang, Z. Zhou, Aust. J. Chem. 62 (2009) 1690-1694.

[13] L.H. Lin, C.C. Wu, C.H. Lai, T.C. Lee, Chem. Mater. 20 (2008) 4475-4483.

[14] J. Ning, K. Men, G. Jun, L. Zhao, L. Wang, B. Liu, B. Zou, J. Colloid Interface Sci. 347 (2010) 172-176.

[15] A. Datta, S. Gorai, D. Ganguli, S. Chaudhuri, Mater. Chem. Phys. 102 (2007) 195-200.

[16] M.A. Franzman, R.L. Brutchey, Chem. Mater. 21 (2009) 1790-1792.

[17] J.B. Shi, C.J. Chen, Y.T. Lin, W.C. Hsu, Y.C. Chen, P.F. Wu, Nanoscale Res. Lett. 4 (2009) 1059-1063.

[18] Y.H. Kim, J.H. Lee, D.W. Shin, S.M. Park, J.S. Moon, J.G. Nam, J.B. Yoo, Chem. Commun. 46 (2010) 2292-2294.

[19] L. Liu, H. Liu, H.Z. Kou, Y. Wang, Z. Zhou, M. Ren, M. Ge, X. He, Cryst. Growth Des. 9 (2009) 113-117.

[20] Y. Xing, H. Zhang, S. Song, J. Feng, Y. Lei, L. Zhao, M. Li, Chem. Commun. (2008) 1476-1478.

[21] C.D. Lokhande, A. Ennaoui, P.S. Patil, M. Giersig, K. Diesner, M. Muller, Thin Solid Films 340 (1999) 18.

[22] S.S. Wang a, F.J. Shiou a, C.C. Tsao b, S.W. Huang c, C.Y. Hsu, Mater. Sci. Semicond. Process. 16 (2013) 1879-1887.

[23] R.S. Mane, C.D. Lokhande, Mater. Chem. Phys. 78 (78) (2002) 15.

[24] R. Nomura, K. Konishi, H. Matsuda, Thin Solid Films 198 (1990) 339.

[25] L. Bhira, H. Essaidi, S. Belgacem, G. Couturier, J. Salardenne, N. Bareau, J.C. Bernède, Solid State Phys. 181 (2000) 427.

[26] S. Spiering, A. Eicke, D. Hariskos, M. Powalla, N. Naghavi, D. Lincot, Thin Solid Films 451/452 (2004) 562.

[27] M. Amlouk, M.A. Ben Said, N. Kamoun, S. Belgacem, N. Brunet, D. Barjon, Jpn. J. Appl. Phys. 38 (1999) 26.

[28] A. Timoumi, H. Bouzouita, M. Kanzari, B. Rezig, Thin Solid Films 480/481 (2005) 124.

[29] T. Asikainen, M. Ritala, M. Leskela, Appl. Surf. Sci. 82 (83) (1994) 122.
[30] M. Roy, B.P. Mandal, D.P. Dutta, A.K. Tyagi, Scr. Mater. 63 (2010) 93.

[31] W.T. Kim, C.D. Kim, J. Appl. Phys. 60 (7) (1986) 2631.

[32] T. Yoshida, K. Yamaguchi, H. Toyoda, K. Akao, T. Sugiura, H. Minoura, Y. Nosaka, Electrochem. Soc. Proc. 97 (20) (1997) 37.

[33] Y.Y. asaki, N. Sonoyama, T. Sakata, J. Electroanal. Chem. 469 (1999) 116.

[34] N. Kamoun, J. Appl. Phys. 89 (5) (2001) 2766.

[35] N. Barreau, S. Marsillac, D. Albertini, J.C. Bernede, Thin Solid Films 403-404 (2002) 331-334.

[36] N. Barreau, J.C. Bernede, H. El Maliki, S. Marsillac, X. Castel, J. Pinel, Solid State Commun. 122 (2002) 445-450.

[37] V.M. Koleshko, A.V. Gulai, V.I. Lyakh, Vacuum 40 (6) (1990) 517-520.

[38] O. Lupan, T. Pauporte, L. Chow, B. Viana, F. Pelle, L.K. Ono, Appl. Surf. Sci. 256 (2010) 1895

[39] G. Binning, C.F. Quate, C.h. Gerber, Phys. Rev. Lett. 56 (1986) 930.

[40] A.M. Chaparro, C. Maffiotte, E. Reccins, H. Sobotta, B. Schumann, G. Huhu, Thin Solid Films 358 (2000) 22.

[41] D. Gherouel, I. Gaied, K. Boubaker, N. Yacoubi, M. Amlouk, J. Alloys Compd. 545 (2012) 190.

[42] P.P. Sahay, R.K. Nath, Sens. Actuators B: Chem. 2 (2008) 654-659.

[43] S. Belgacem, R. Bennaceur, Appl. Phys. Rev. 25 (1990) 1245.

[44] F. Yakuphanoglu, A. Cukurovali, I. Yilmaz, Opt. Mater. 27 (2005) 1363-1368.

[45] H.G. Tompkins, W.A. McGahan, Spectroscopic Ellipsometry and Reflectometry, John Wiley and Sons Inc., USA, 1999.

[46] S.H. Wemple, M. DiDomenico, Phys. Rev. B 3 (1971) 1338.

[47] S.H. Wemple, Phys. Rev. B 7 (1973) 3767.

[48] A. Boukhachem, B. Ouni, M. Karyaoui, A. Madani, R. Chtourou, M. Amlouk, Mater. Sci. Semicond. Process. 15 (2012) 282.

[49] F. Yakuphanoglu, A. Cukurovali, I. Yilmaz, Physica B 351 (2004) 53.

[50] E.A. Davis, N.F. Mott, Philos. Mag. 22 (1970) 903.

[51] M.J. Newell, R., Engelken, J., Hall, M.A., Mughal, F.,Felizco , J., Vangilder, S.,Thapa, D.,McNew , Z.,Hill , B.R., Carroll, Elemental sulfur-based electrodeposition of indium sulfide films. in: Proceedings of the 37th IEEE Photovoltaics Specialists Conference, 2011, pp. 1322-1326.

[52] J.C. Bernède, N. Barreau, Thin film photovoltaic cell, especially a copper-indium selenide based solar cell, has beta-indium oxysulfide buffer layer between absorbent photoconductive layer and transparent conductive layer, Patent FR19980010603 19980821, 2000.

[53] R. Simha, T. Somcynsky, Macromolecules 2 (1969) 342.

[54] R. Simha, P.S. Wilson, Macromolecules 6 (1973) 908.

[55] K. Boubaker, ISRN Nanomater. 2012 (2012) 4, http://dx.doi.org/ $10.5402 / 2012 / 173198$

[56] K. Boubaker, J. Ceram. 2013 (2013) 6, http://dx.doi.org/10.1155/2013 734015. (Article ID 734015).

[57] K. Boubaker, M. Amlouk, Y. Louartassi, H. Labiadh, J. Aust. Ceram. Soc. 49 (1) (2013) 115-117.

[58] P. Petkova, K. Boubaker, J. Alloys Compd. 546 (5) (2013) 176-179.

[60] H.Y. Cheng, J.S. Ma, C.H. Lu, J. Alloys Compd. 543 (2012) 84-89.

[61] Y.B. He, L.H. Wang, L. Zhang, M.K. Li, X.Z. Shang, Y.Y. Fang, C.Q. Chen, J. Alloys Compd. 534 (2012) 81-85.

[62] F. Charpentier, M. Dussauze, M. Cathelinaud, G. Delaizir, E. I. Kamitsos, J.L. Adam, B. Bureau, V. Nazabal, J. Alloys Compd. 5097 (2011) 7330-7336. 